Acta vet. scand. $1977, \mathbf{1 8}, \mathbf{5 7 2}-\mathbf{5 7 4}$.

Brief Communication

\title{
GENETIC VARIATIONS IN THE ANTIBODY RESPONSE IN YOUNG BULLS
}

Considerable evidence for the existence of a direct genetic control of the immune response has been presented during recent years. Experimental work with rodents are the main basis for this evidence. The first study on genetic variations in the antibody response was carried out by Gorer \& Schütze (1938). Later Cinader (1960) published detailed considerations about the specificity and inheritance of the antibody response. In mice it has been demonstrated that a few dominant immune response (Ir) genes determine the ability to produce antibodies against certain specific antigens (McDevitt \& Tyan 1968). The magnitude of the response is probably under the influence of polygenes, which are not associated with Ir genes. This theory is supported by selection for high and low antibody production in mice (Biozzi et al. 1972).

The purpose of the present investigation was to study the variation in the antibody response to a specific antigen in young bulls. The study was carried out at the Bull Test Station at $\emptyset$ yer, Norway. The test material, comprising 137 bulls from 116 to 427 days of age, were arranged in $\mathbf{1 5}$ groups of half brothers. There were from 2 to 26 animals in each group. The bulls were placed in the same environment, in which feeding was standardized with regard to age. Human albumin ${ }^{*}$ was chosen as immunizing antigen, since the bulls had presumably experienced no previous contact with this compound. Consequently, each bull should possess approximately the same specific ability to produce an immune response, when genetic and age variations are not considered. Human albumin, dissolved and diluted in $0.9 \%$ saline, was mixed in equal proportions with the adjuvant** to a final concentration of $500 \mu \mathrm{g}$ per ml. Two doses, each of $4 \mathrm{ml}$, were given

* Human-Albumin, dried, purified, ORHA 04 , Behringwerke AG, Marburg Lahn, W. Germany.

* Adjuvant. Incomplete, Freund, Difco Laboratories, Detroit 1, Michigan, USA. 
subcutaneously to each bull with an interval of about 5 weeks. Blood samples were drawn before immunization and at intervals of about 5 days, in addition to the daily samples collected at the time of the expected peak of the secondary immune response. The evaluation of the antibody titre was performed by the single radial immunodiffusion technique (Mancini et al. 1965). An agarose $^{\star}$ gel of $1 \%$, in which human albumin was present at a concentration of $10 \mu \mathrm{g}$ per $\mathrm{ml}$, was prepared. Serum samples from the bulls were applied into wells with diameters of $3 \mathrm{~mm}$ in the agarose gel, which was $2 \mathrm{~mm}$ in thickness. The diameters of the precipitin rings were measured after incubation at $4^{\circ} \mathrm{C}$ for $72 \mathrm{hrs}$. The correlation ( $r$ ) between the size of the precipitin areas, expressed as squares of the diameters $\left(D^{2}\right)$, and the antibody concentrations $(C)$ was estimated to be $0.999(P<0.0005)$. The simple regression equation of $\mathrm{C}$ on $\mathrm{D}^{2}$ could be written as $\tilde{E}\left(C \mid D^{2}\right)=12.020+0.827 D^{2}$, where $C$ is expressed in diffusion units as described by Sandvik (1962). This equation, when graphically expressed, acted as calibration curve during the antibody response investigation.

Anti human albumin antibodies were not detected in any of the blood samples collected before immunization.

The average immune response curve of the whole material followed a typical course with a peak titre of the primary response at about 14 to 16 days after the first inoculation.

A secondary response about eightfold larger than the primary one, had its peak level about $7-8$ days after the second administration. Variations between and within groups of halfbrothers, besides variations of age with regard to certain immune response characteristics were observed. Peak antibody titre of the secondary response was used as the phenotypic criterion of immune response capacity. Mean peak titre of the total material was $17.02 \pm 16.95$ (mean $\pm s$ ) diffusion units. The relationship between antibody production and age is expressed as follows:

\begin{tabular}{|c|c|c|c|c|c|}
\hline Age (days) & $113-147$ & $148-161$ & $162-180$ & $181-220$ & $221-420$ \\
\hline $\begin{array}{l}\text { Per cent observations } \\
\text { above mean peak titre } \\
\text { (17.02 diffusion units) }\end{array}$ & 5 & 31 & 50 & 54 & 57 \\
\hline
\end{tabular}

* Agarose, batch no: AGS 192, Litex, postboks 7, DK-2600 Glostrup, Denmark. 
In order to correct for age, 8 small groups with extreme values of age, besides bulls with extreme values of age within groups, were excluded. Multiple tests revealed significant differences within 5 of 21 possible pairs of groups with regard to peak antibody titre $(0.01<\mathrm{P}<0.05)$.

The 7 groups, tested as a whole, differed almost significantly at the level of $0.05(F=1.94$, d.f. $=6$ and 75$)$.

To separate the effect of age from that of inheritance, the method of least squares was performed on a material comprising all 137 bulls. The differences between groups, with respect to peak titre, were not quite significant at the level of $0.05(F=1.40$, d.f. $=14$ and 117). Accordingly, the heritability estimate of peak titre was not quite significant either $\left(h^{2}=0.18 \pm 0.24\right)$.

However, in view of the significant differences between some of the groups and the rather high heritability estimated, these preliminary results might support the assumption of a genetic influence on the magnitude of the antibody response in cattle.

Øystein Lie

The National Veterinary Institute, Oslo, Norway.

\section{REFERENCES}

Biozzi, G., C. Stiffel, D. Mouton, Y. Bouthillier \& C. Decreusefond: Cytodynamics of the immune response in two lines of mice genetically selected for "high" and "low" antibody synthesis. J. exp. Med. 1972, 135, 1071-1094.

Cinader, B.: Specificity and inheritance of antibody response: A possible steering mechanism. Nature (Lond.) 1960, 188, 619-622.

Gorer, P. A. \& H. Schütze: Genetical studies on immunity in mice. J. Hyg. (Lond.) 1938, 38, 647-662.

Mancini, G., A. O. Carbonara \& J. F. Heremans: Immunochemical quantitation of antigens by single radial immunodiffusion. Immunochemistry $1965,2,235-254$.

McDevitt, H.O.\& M.L. Tyan: Genetic control of the antibody response in inbred mice. J. exp. Med. 1968, 128, 1-11.

Sandvik, O.: Studies on casein precipitating enzymes of aerobic and facultatively anaerobic bacteria. Thesis, Veterinary College of Norway, Oslo 1962.

(Received November 4, 1977).

Reprints may be requested from: Øystein Lie, The National Veterinary Institute, Postbox 8156, Oslo Dep., Oslo 1, Norway. 